\author{
Dariusz Tłoczyński \\ University of Gdańsk \\ e-mail: dariusz.tloczynski@ug.edu.pl \\ ORCID: 0000-0001-6262-1062
}

\title{
SERVICE ON BOARD AN AIRCRAFT AS AN INSTRUMENT OF SHAPING THE IMAGE OF AIR CARRIERS
}

\section{OBSEUGA NA POKLADZIE SAMOLOTU JAKO INSTRUMENT KSZTALTOWANIA WIZERUNKU PRZEWOŹNIKÓW LOTNICZYCH}

DOI: $10.15611 / \mathrm{pn} .2020 .1 .15$

JEL Classification: R49

\begin{abstract}
Summary: As a result of activities on the competitive air transport market, operators provide innovative products that are designed to achieve the company's objectives. In addition to the typical services offered, the human capital management process plays an important role in attracting new passengers. One of the elements of shaping the air carrier's image is inflight service. After the journey, the passenger assesses all elements, at the same time stating that on-board service, despite being carried out at a high quality level, is not a factor clearly influencing the decision to purchase an air service. As a result of the author's own marketing research at Polish airports, using a direct interview, it was found that in-flight service has a neutral effect on the decision to choose an air carrier. This situation shows that there is a need to conduct research assessing what elements and to what extent they influence the decision to choose an air carrier.
\end{abstract}

Keywords: air transport, cabin crew, air cariers, flight attendant, transport service, on-board service.

Streszczenie: W wyniku działań na konkurencyjnym rynku przewozów lotniczych operatorzy dostarczają innowacyjne produkty mające doprowadzić do osiągnięcia założonych celów przedsiębiorstwa. Oprócz typowej oferty usługowej, ważną rolę w pozyskaniu nowych pasażerów odgrywa proces zarządzania kapitałem ludzkim. Jednym z elementów kształtowania wizerunku przewoźnika jest obsługa pokładowa. Pasażer po odbytej podróży ocenia wszelkie czynniki, jednocześnie stwierdzając, że obsługa pokładowa, mimo iż jest na wysokim poziomie jakościowym, nie jest czynnikiem jednoznacznie wpływającym na podejmowanie decyzji o zakupie usługi lotniczej. W wyniku autorskich badań prowadzonych w polskich portach lotniczych metodą wywiadu bezpośredniego stwierdzono, że obsługa pokładowa wpływa w sposób neutralny na podjęcie decyzji o wyborze przewoźnika lotniczego. W związku z tym 
nie ma potrzeby podejmowania badań oceniających, jakie czynniki i w jakim zakresie mają wpływ na podejmowanie decyzji o wyborze przewoźnika.

Słowa kluczowe: transport lotniczy, załoga pokładowa, przewoźnicy lotniczy, stewardesa/ steward, usługa przewozowa, serwis pokładowy.

\section{Introduction}

Air transport has a great impact on shaping global economic processes. Technology development, integration and globalization have a significant influence on shaping and launching innovative products on the market. Air carriers are trying to implement new generations of products (in marketing terms) to attract new customers, while at the same time meeting the ever-evolving needs of transport service buyers - the passengers. At the same time, air operators and other institutions conduct a number of market research analysing the purchasing decision-making process and transport behaviour, even though manufacturers of aviation equipment as well as carriers are constantly introducing innovative aviation products, wishing to achieve market success. Marketing analysts thus create the image of the airline, skilfully managing flight personnel to fully meet the needs of passengers.

In view of the above conditions, the main research goal was set: do the onboard crew and flight attendants' behaviour affect the choice of an air carrier? The main thesis follows: due to similar marketing instruments shaping the image of the company, air carriers offer a similar product i.e. in-flight service, which has no decisive influence on the decision to choose an airline.

\section{Marketing of airlines}

Marketing aims to recognize and meet human and social needs. Ph. Kotler and K.L. Keller provide one of the shortest definitions of marketing - meet the needs, making a profit [Kotler, Keller 2012]. The American Marketing Association defines marketing as a business, set of institutions and processes for creating, communicating, and delivering products that have value for customers, contractors and society [AMA 2017]. Although a lot of marketing definitions can be found in the literature, these issues are analysed, among others, by Morden, Hooley et al., Locander et al., Wright, Ferrel and Drucker [Morden 1993; Hooley, Saunders, Piercy 1998; Locander, Cocanougher (eds.) 2011; Wright 1999; Ferrell, Lucas 1987; Drucker 1973], however, a typical classic definition of marketing is attributed to Kotler: "Marketing is a social and management process by which specific individuals and groups receive what they need and want to achieve by creating, offering and exchanging valuable products" [Kotler 1994].

In the air transport sector, all marketing-related regularities also apply. Doganis [2010] demonstrates the marketing goal of the transport operations of carriers focused on consumer satisfaction and their needs: "If an airline concentrates on merely 
selling what is produced before identifying what customers want and are prepared to pay for, it is doomed to failure". Thus, the verifiers of the services purchased are the consumers - the purchasers of transport services.

In view of the above conditions, there is a necessity to define the needs, expectations and manner of the transport behaviour of consumers (passengers). Market segmentation is the division of the population according to specific or specified criteria into homogeneous groups of consumers (market segments), which determine the area of activity for the enterprise and constitute a reference point for:

- formulating its market strategy,

- targeting the market,

- positioning of products offered [Ruciński et al., 2012].

The segmentation of air transport passengers is the process of dividing air service buyers into as homogeneous groups as possible, separated from all buyers on the basis of specific socio-economic, demographic, psychographic and other criteria. The criterion of segment homogeneity is the occurrence of specific common features perceived as typological features of a given group of buyers [Shaw 2011]. Segmentation analysis is the basis for identifying their homogeneous group, segment or segments to adapt marketing activities to their characteristics and reported preferences or needs.

The literature related to the economics of air transport indicates three segments of passengers [Graham, Halpern 2013; Grumbridge 2014]:

- business air travel,

- leisure air travel,

- charter air travel.

According to McDonald and Dunbar, segmentation is the process of dividing customers from one market into different segments (parts), in which their needs and market behaviour are similar and can be satisfied with a properly configured marketing composition. As an element of marketing, segmentation leads to transformation of the differences between products into cost distinguishing features that can be maintained throughout the product's life cycle [McDonald, Dunbar 2003]. In this context, segmentation is an important factor in adding value to an enterprise.

Table 1. Characteristics of selected segments - passengers of air services

\begin{tabular}{|l|l|l|l|}
\hline \multicolumn{1}{|c|}{ Specification } & Business air travel & \multicolumn{1}{c|}{ Leisure air travel } & Charter air travel \\
\hline flexibility towards the price & low & high & medium \\
\hline travel frequency & high & low & very low \\
\hline using loyalty programs & often & occasionally & no \\
\hline on-board shopping & occasionally & rarely & very often \\
\hline in-flight service & very often & often & rarely \\
\hline
\end{tabular}

Source: own study. 
To adapt their services to selected segments, air carriers implement a traditional marketing-mix composition:

- product,

- price,

- distribution,

- promotion.

\section{Product analysis in airline marketing}

Air carries provide different products depending on the segment. Air carriers increasingly offer diverse service packages, causing the so-called synergistic effect, which means that the individual elements of the air service together present a greater benefit for the recipient (added value) than when offered separately [Głowacki 1984]. Using Rogers' principles, it is possible to suggest that a new product must show at least the following characteristics if they are to be long-term successes:

- relative advantage,

- compatibility,

- complexity,

- divisibility,

- communicability [Rogers 1995].

The indicated features lead to offering a diversified product. The offered product affects the feelings of passengers and is one of the elements of shaping the image of an airline. The product shaping elements include cabin configuration and classes of services; depending on the aircraft type, carriers operating on the market offer different configuration options for the passenger cabin. Most carriers offer four cabin classes: economy, premium economy, business and first class. This configuration is of course connected to the class of travel. In "Extra Large" aircraft, e.g. B747 and A380, there are two decks designed for passengers, the upper is for travelers in First Class, while the lower is for Business, Economy and Economy Premium classes. For smaller "Large" or "Medium" aircraft, the aircraft manufacturer, at the request of an airline, differentiates classes by their distance from the cockpit: first class - the front of the aircraft, then Business, followed by the largest number of seats available - Economy Premium, and then Economy.

Depending on the operator, some seats and the distance between them were reduced in order to more efficiently use the space available for passengers. Although some carriers offer four transport classes, some air operators - only one. This is the case for the so-called Low Cost Carriers (LCC) and in charter flights, but the place in LCC or in charter air carriers can be very different from the economic place of the legacy air carriers (those functioning prior to Airline Deregulation Act of 1978).

Moreover, other factors affecting the airline's product offer are: network, frequencies and timings. Scheduling planning is always a compromise between the carrier's production capacity, the quality offered, the cost and the needs of passengers. 
Table 2. Air transport services offered depending on the transport class

\begin{tabular}{|c|c|c|c|}
\hline Economy & Economy Premium & Business & First \\
\hline $\begin{array}{l}\text { The seats are narrowest, } \\
\text { from } 16 \text { inches to just } \\
\text { over } 19 \text { inches wide, } \\
\text { and the spacing of seats, } \\
\text { distance from one seat } \\
\text { to another, economy } \\
\text { class is the most basic } \\
\text { class. Most often in } \\
\text { this class, carriers offer } \\
\text { flights, although some } \\
\text { airlines, such as jetBlue } \\
\text { and Hawaiian Airlines, } \\
\text { offer free snacks and } \\
\text { drinks and in-flight } \\
\text { entertainment systems. } \\
\text { British Airways offers } \\
\text { attractive prices and } \\
\text { a convenient network, } \\
\text { as well as profiled, } \\
\text { leather seats fully } \\
\text { movable headrests, } \\
\text { free newspapers for } \\
\text { most flights, modern } \\
\text { LED lighting that } \\
\text { adapts during the flight, } \\
\text { snacks, some of the } \\
\text { snacks are paid, basic } \\
\text { economic tariff includes } \\
\text { hand baggage, fare } \\
\text { Plus - includes checked } \\
\text { baggage and provides } \\
\text { additional booking } \\
\text { flexibility, Plus Flex fare } \\
\text { provides the greatest } \\
\text { flexibility. Traveling } \\
\text { with family on British } \\
\text { Airways, you will } \\
\text { find many thoughtful } \\
\text { elements and will make } \\
\text { toddlers happy and } \\
\text { entertaining during the } \\
\text { flight, BA offers priority } \\
\text { children in prams, free } \\
\text { pabies famd small }\end{array}$ & 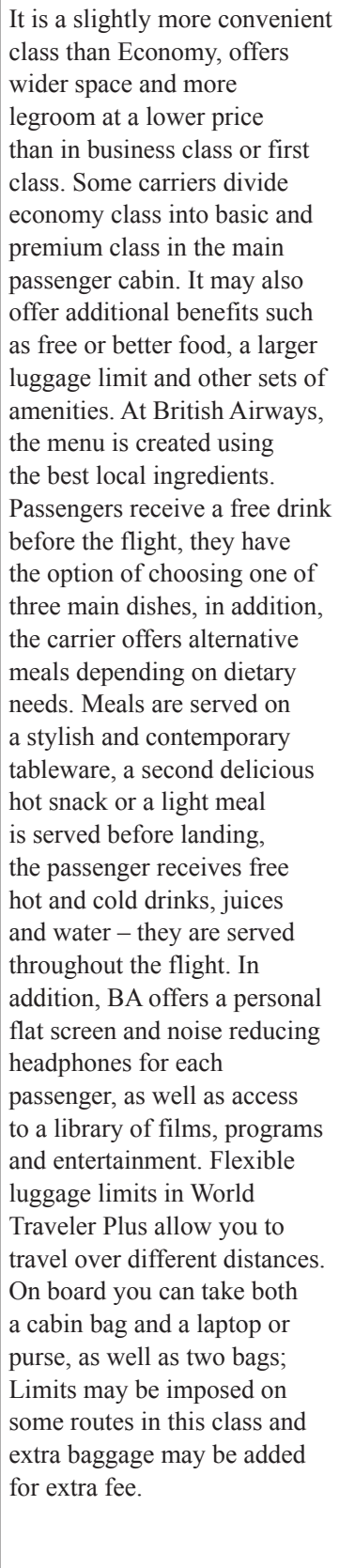 & $\begin{array}{l}\text { Passengers receive } \\
\text { a high standard of } \\
\text { service from the carrier, } \\
\text { it includes a wider seat } \\
\text { that tilts back but does } \\
\text { not lie flat, a full meal, } \\
\text { entertainment during the } \\
\text { flight and a set } \\
\text { of accessories necessary } \\
\text { for travel. British } \\
\text { Airways offers access } \\
\text { to comfortable lounges } \\
\text { in terminals, priority for } \\
\text { boarding aircraft, more } \\
\text { personal space on the } \\
\text { deck to work or relax, } \\
\text { free food and drink, } \\
\text { dedicated check-in } \\
\text { desks, greater baggage } \\
\text { allowance. The carrier } \\
\text { provides a free middle } \\
\text { seat, thanks to which the } \\
\text { passenger is guaranteed } \\
\text { a window seat or aisle } \\
\text { seat, profiled leather } \\
\text { armchairs with } 30 \text { inch } \\
\text { seat spacing, fully } \\
\text { movable headrests, } \\
\text { modern LED lighting } \\
\text { that adapts during the } \\
\text { flight, free newspapers } \\
\text { for most flights, } \\
\text { dedicated cabin crew } \\
\text { caring for business } \\
\text { passengers on board. }\end{array}$ & $\begin{array}{l}\text { The most luxurious travel } \\
\text { class, carriers offer from } \\
\text { individualized lounges to } \\
\text { stylish apartments. British } \\
\text { Airways works with the } \\
\text { best chefs in the world } \\
\text { and British designers } \\
\text { to ensure that the meals } \\
\text { offered are of the highest } \\
\text { quality. The carrier offers } \\
\text { luxury meals, including } \\
\text { a new delicious à la carte } \\
\text { menu, and a number } \\
\text { of lighter dishes that } \\
\text { focus on fresh seasonal } \\
\text { ingredients. The passenger } \\
\text { menu will include } \\
\text { a selection of sandwiches, } \\
\text { delicate pastries and } \\
\text { rolls, as well as a wide } \\
\text { selection of tea infusions, } \\
\text { coffee and a wide } \\
\text { selection of champagnes, } \\
\text { wines, alcoholic and } \\
\text { non-alcoholic beverages } \\
\text { within the ticket price. } \\
\text { Also the passenger } \\
\text { obtains a dedicated } \\
\text { check-in desks at most } \\
\text { airports, priority boarding, } \\
\text { executive lounge, special } \\
\text { care for cabin crew on } \\
\text { board airplanes, free } \\
\text { access to the full range } \\
\text { of amenities on board } \\
\text { airplanes. }\end{array}$ \\
\hline
\end{tabular}

Source: [Internet 1; Internet 2]. 
In many cases, there are also government regulations, navigation agencies and contracts. The factor that affects the carrier's image is punctuality. Obviously for many air carriers the problem is congestion in the air and at airports. According to CNN [Internet 3], in 2019 the most punctual carriers are Copa Airlines (non-delay rate 89.78\%), airBaltic (89.17\%), and Hong Kong Airlines (88.11\%). However, many factors affect punctuality, including fleet and personnel management, and time spent at airports. Gdańsk Airport is a leader on the domestic market in check-in punctuality (factor $86.16 \%$, average delay 20 minutes).

In addition to the above factors, the product image of the airline is also affected by other product factors:

- point-of sale service,

- reservations and overbooking,

- airport service,

- baggage service,

- in-flight service.

\section{On-board service as an element of promotion}

The promotional policy pursued by air carriers concerns the sharing of information that contributes to achieving the company's planned goals. The main purpose of the promotion is to convey a message to customers on target markets that the carrier is available at the right time, place and price. This situation requires a proper mix of promotional activities - a combination that best suits a specific market [Wensveen 2017].

The promotion policy is an instrument of competition because, through information, the carrier provides data on:

- shaping the air service, e.g. new air connections, new offer of additional services for passengers,

- prices of services offered,

- service availability,

- $\quad$ shaping the image of the airline company [Tłoczyński 2016].

The airline's main representative is a flight attendant. The role of the cabin crew is very similar to the service on passenger ships or on trains. On the plane, the cabin crew's role is more involved because it results from the natural restrictions existing during the flight. Stewardesses and stewards on board of the aircraft together make up the flight crew, unlike the pilots and engineers in the cockpit. The number of cabin crew depends on the type of aircraft and the class of travel. The main task of the flight crew is to attend to the needs of passengers during the flight. In addition to serving meals, alcoholic and non-alcoholic beverages, first of all, the cabin attendant ensures the safety of all persons on board the aircraft. In accordance with ICAO procedures, the number of cabin crew on board and their efficiency is related to safety aspects (evacuation of passengers from an aircraft). Hence, the regulations set 
a minimum number of cabin crew to effectively evacuate and increase the chances of survival of passengers in an accident [ICAO 2017]. On the other hand, the right number of cabin crew is designed to provide high quality service, create the right atmosphere, relations with passengers, and also create a positive image of the carrier so that the passenger/customer again uses the same airline.

The profession of cabin crew requires a lot of self-discipline, it is also necessary to be able to adapt to changing conditions and flexibility, to always be present at work and be open/open to the attention of passengers. The continuous training system aims to deepen knowledge of emergency situations, first aid, safety regulations and service procedures. Examples of passenger service procedures on board the aircraft are presented in Table 3.

Table 3. On-board passenger service procedures

\begin{tabular}{|c|c|c|c|}
\hline $\begin{array}{c}\text { SCA-Senior } \\
\text { Cabin Attendant - head } \\
\text { of on-board crew, } \\
\text { the flight manager }\end{array}$ & $\begin{array}{c}\text { CA2 - Cabin } \\
\text { Attendant } 2- \\
\text { the person in the front } \\
\text { seat next to the flight } \\
\text { manager }\end{array}$ & $\begin{array}{l}\text { CA2 - Cabin } \\
\text { Attendant } 3-\text { sits } \\
\text { at the back } \\
\text { to the right }\end{array}$ & $\begin{array}{c}\text { CA2 }- \text { Cabin } \\
\text { Attendant } 4-\text { sits in the } \\
\text { back to the left }\end{array}$ \\
\hline $\begin{array}{l}\text { Works at the front of the } \\
\text { plane } \\
\text { During the service, serves } \\
\text { the on-board terminal (cash } \\
\text { register, payment terminal), } \\
\text { standing in front of the } \\
\text { passenger } \\
\text { Gives out information } \\
\text { Maintains contact with } \\
\text { the cockpit crew and } \\
\text { has the right to enter the } \\
\text { cockpit (under normal } \\
\text { circumstances) }\end{array}$ & $\begin{array}{l}\text { Works at the front with } \\
\text { the head of flight } \\
\text { Sells products that } \\
\text { have been ordered by } \\
\text { a passenger } \\
\text { When providing the } \\
\text { service, faces the } \\
\text { passenger }\end{array}$ & $\begin{array}{l}\text { During the } \\
\text { service, serves } \\
\text { the on-board } \\
\text { terminal (cash } \\
\text { register, payment } \\
\text { terminal), facing } \\
\text { the passenger } \\
\text { Hands out menus }\end{array}$ & $\begin{array}{l}\text { Advises the passenger } \\
\text { on the products they } \\
\text { order } \\
\text { When providing the } \\
\text { service, faces the } \\
\text { passenger }\end{array}$ \\
\hline
\end{tabular}

Source: airline internal materials.

An inseparable element of shaping the image of an air carrier is its image and behaviour. The cabin crew uniform depends on the organizational situation of the inflight service. Carrier standards distinguish formal and service clothing. While the latter is adapted to the activities of preparation, serving and cleaning after meals on the plane, the elegant version follows the airline dress code. The most commonly used colours are: blue, navy blue, black, grey - these refer to the tradition and corporate colour of the company. Women's shoes must have low heels, and importantly, should be appropriate for the figure and the situation of the attendant during the flight. In addition to the dress code, the image is influenced by properly combed and styled hair, emphasizing elegance and stylized hats, makeup and accessories (watch, rings), as well as scarves (tied with a single or double knot to the side) and ties (most often 
tied with a Windsor knot). An additional factor is the approach to each passenger with the right smile, listening to their expectations. In addition, the cabin crew should take care of good posture, maintain eye contact with passengers, ask questions, be interested in the situation on board the aircraft, move slowly with the trolley - bar or accessories, through the cabin asking each person individually whether they would like to buy something and suggesting a purchase, and in difficult situations to be consistent, determined and assertive.

On board the aircraft, all information materials related to the type of aircraft, safety instructions, as well as headrests, electronic displays carry a logo. Passengers have the option of purchasing carrier identification accessories, e.g. model airplanes, luggage tags, some elements of the aviation uniform, pens, etc.

The promotional policy carried out on the aircraft is the most important element affecting the purchase of air services. Passengers usually have competitive carriers to choose from, based on their previous experience.

\section{Assessment of in-flight service by passengers using Polish airports}

On the basis of research carried out at Polish airports regarding assessment of the functioning of the air transport system, the functioning of in-flight service was assessed. For $1 \%$ of respondents, service had the greatest impact on the choice of the air carrier, and for $1 \%$ of respondents, service was in second place. However, for $33 \%$ the service on board was a factor encouraging the choice of the carrier, and for $65 \%$ it was a neutral factor.

However, the analysis of in-flight service is different for individual segments. Passengers travelling with a low-cost carrier had a similar opinion on service as passengers traveling with the 'legacy air carriers'.

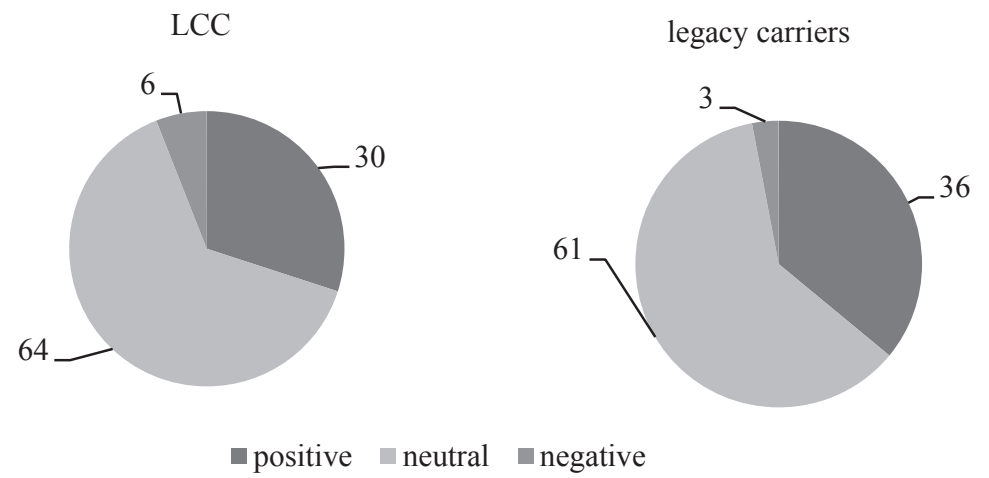

Fig. 1. The role of in-flight service on the choice of airline

Source: own marketing research. 
In-flight service was the most neutral factor for passengers travelling with lowcost carriers and legacy air carriers. On the other hand, the majority of respondents for whom the service was a factor encouraging the choice of the carrier there were passengers using the services of 'network carriers' (36\%) than those using LCC (30\%).

Passengers using the services of the low-cost carrier Wizz, indicated in $28 \%$ of cases service on board the aircraft as an element encouraging them to choose the airline, while Ryanair passengers $-31 \%$, easyJet $-33 \%$, and those of Norwegian Air Shuttle $-36 \%$.

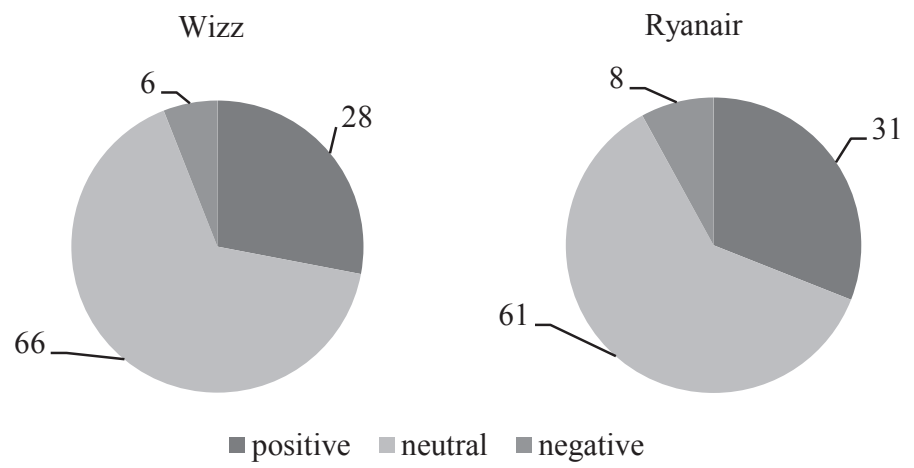

Fig. 2. The role of in-flight service in the selection of certain low-cost carriers

Source: own marketing research.

On the other hand, in the legacy carriers segment, for $34 \%$ of passengers using Polish Airlines in-flight service it was satisfactory, Lufthansa - 36\%, SAS $-24 \%$ and Emirates $-86 \%$, which indicates that more attention is paid to in-flight service on long-haul routes, especially in the Middle East.
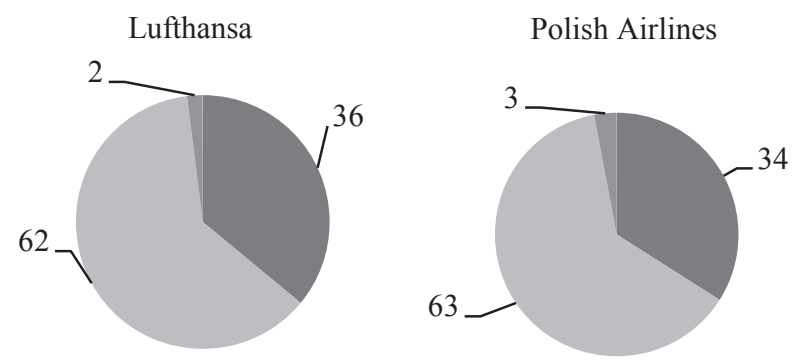

Emirates

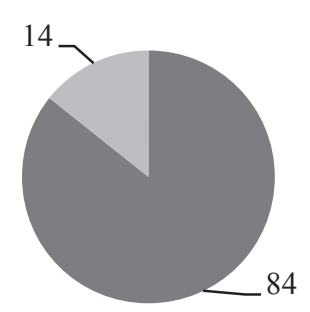

$\square$ positive $\square$ neutral $\square$ negative

Fig. 3. The role of in-flight service in the selection of certain legacy air carriers

Source: own marketing research. 
During the analysis of the so-called legacy carriers, the class of travel was also taken into account (in no-domestic journeys). In economy class, 35\% of passengers indicated in-flight service as a factor encouraging the choice of a carrier, while for $62 \%$ it was a neutral factor, and for $3 \%$ it was a negative factor. In business class, however, in-flight service was a much more attractive factor - more $50 \%$ of respondents indicated that service on board is an element encouraging the choice of air service, as well as being a neutral factor.

For passengers travelling in business class, for $2 \%$ service during the flight was the most important factor influencing their decision to choose a given carrier (in economy class $-1 \%$ ).

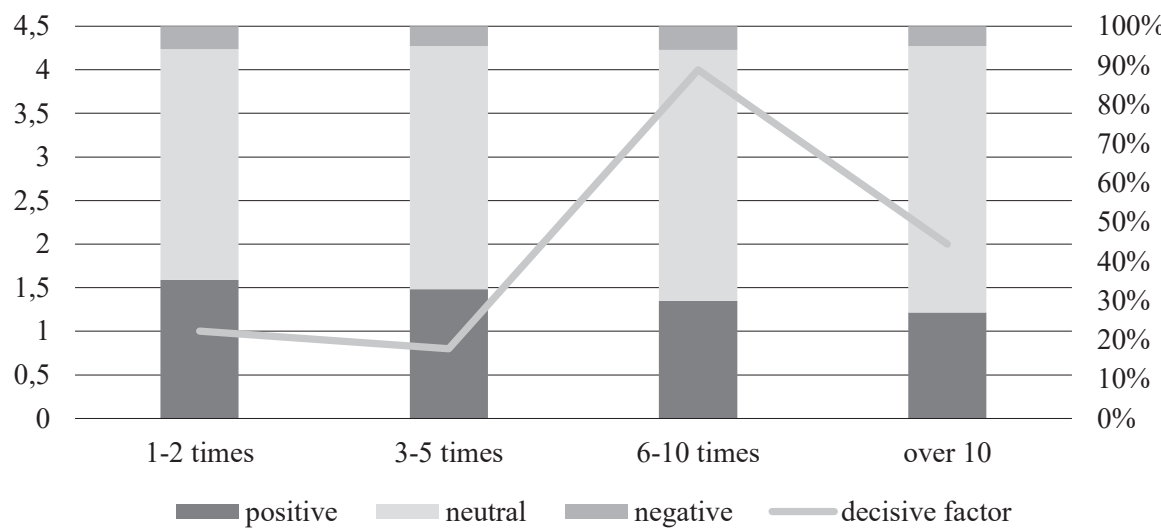

Fig. 4. The role of in-flight service depending on the frequency of travel

Source: own marketing research.

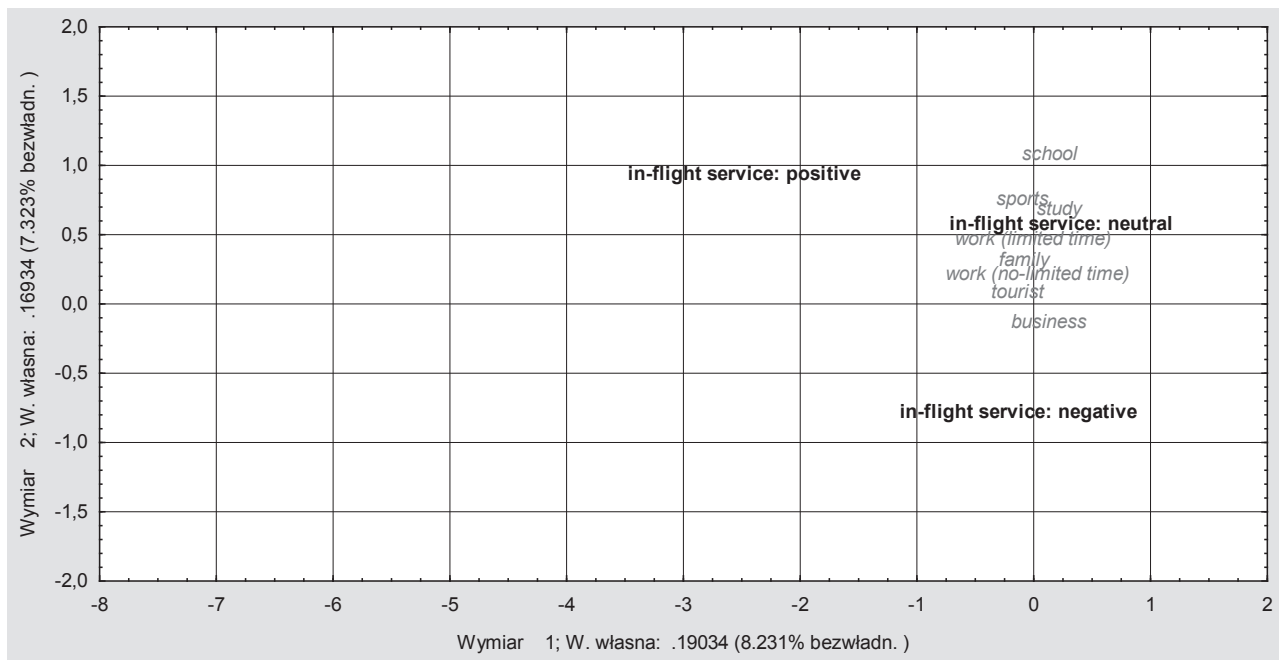

Fig. 5. The role of in-flight service depending on the type of travel

Source: own marketing research. 
Depending on the frequency, passengers rated the service on board the aircraft as a neutral factor not having a major impact on the choice of airline. The most important element influencing the choice was the in-flight service for frequent travelers (6-10 times a year) $-4 \%$, and those travelling very often (over 10 times) $-2 \%$.

Depending on the type of travel, passengers travelling to school, university and sporting events indicated that service on board positively influences the choice of carrier. On the other hand, persons on business trips said that the quality of in-flight service negatively affects the choice of the carrier.

\section{Conclusion}

The subject literature on indicates that market entities should take care of the service they provide. In the air transport market, entities in accordance with marketing principles implement a strategy to shape the company's image. Activities consisting in improving and introducing new, innovative solutions to the market, of course, are accepted by passengers. In-flight service varies depending on the type of travel class. Carriers offer a similar product, including wider seats, greater distances between seats, meals, the possibility of using the entertainment area, or even possibilities related to relaxation. Crew management is another instrument, i.e. their care for safety, comfort, meeting passengers' expectations, and their full identification with the company's identity. However, in-flight service is not a factor determining the choice of airline. Nearly $30 \%$ of respondents said that in-flight service encourages making the choice of carrier. In turn, $60 \%$ believe that this element has no impact on the choice of operator (it is neutral).

To conclude, the thesis can be confirmed that in-flight service, although it depends on the carrier's operating model (LCC or LC) and the class of travel, is an instrument for shaping the image of the air carrier, however, due to the competition in the industry, it is not an element that significantly affects the choice of air carrier.

\section{References}

AMA, 2017, Definition of Marketing, American Marketing Association, www.marketing power.com/ AboutAMA/Pages/DafinitionofMarketing.aspx (29.08.2019).

Doganis R., 2010, Flying of course. Airline Economics and Marketing, Routledge, London and New York.

Drucker P., 1973, Marketing: Task, Responsibilities, Practices, Harper and Row, New York.

Ferrell O.C., Lucas G.H., 1987, An evaluation of progress in the development of a definition of marketing, Journal of the Academy of Marketing Science, 15(3), p. 12-23.

Głowacki R., Kossut Z., Kramer T., 1984, Marketing, PWN, Warszawa.

Graham A., Halpern N., 2013, Airport Marketing, Routledge, London.

Grumbridge J.L., 2014, Marketing Management in Air Transport, Routledge, London.

Hooley J., Saunders J.A., Piercy N.F., 1998, Marketing strategy and Competitive Positioning, Prentice Hall, Harlow.

ICAO, 2017, Manual on Establishment of Minimum Cabin Crew Requirements (Doc 10072), ICAO. 
Kotler Ph., 1994, Marketing Management: Analysis, Planning, Implementation, and Control, Prince Hall.

Kotler Ph., Keller K.L., 2012, Marketing, Pearson, Dom Wydawniczy Rebis, Poznań.

Locander W.B., Cocanougher A.B. (eds.), 2011, Problem Definition in Marketing, Marketing ClassicPress.

McDonald M., Dunbar I., 2003, Segmentacja, Oficyna Ekonomiczna, Kraków.

Morden A.R., 1993, Elements of Marketing, 3rd edition, DP Publications Ltd, London.

Rogers E.M., 1995, Diffusion of Innovations, 4th edition, The Free Press, New York.

Ruciński A., Rucińska D., Tłoczyński D., 2012, Transport lotniczy. Ekonomika i organizacja, Gdańsk University Press, Gdańsk.

Shaw S., 2011, Airline Marketing and Management, Ashgate, Burlington.

Tłoczyński D., 2016, Konkurencja na rynku ustug transportu lotniczego, Gdańsk University Press, Gdańsk.

Wensveen J.G., 2017, Air Transportation. A Management Perspective, Ashgate, Farnham-Burlington. Wright R., 1999, Marketing: Origins, Concepts, Environment, Business Press, Thomson Learning.

\section{Internet}

[1] www.britishairways.com (29.08.2019).

[2] www.cheapflights.com (29.08.2019).

[3] www.cnn.com (29.08.2019). 